\title{
RESPONSE OF HETEROTROPHIC MICROBIAL COMMUNITIES TO AN ENVIRONMENTAL GRADIENT IN THE FLOODPLAIN OF MAPIRE RIVER, VENEZUELA
}

\author{
Alejandra Zamora-Figueroa ( $\nabla$ alejandra.zamora@ucv.ve) \\ Universidad Central de Venezuela Instituto de Zoología y Ecología Tropical https://orcid.org/0000- \\ 0002-5198-8499 \\ Ismael Hernández-Valencia \\ Universidad Central de Venezuela Instituto de Zoología y Ecología Tropical \\ Nora Malaver \\ Universidad Central de Venezuela Instituto de Zoología y Ecología Tropical
}

\section{Research Article}

Keywords: seasonal changes in the soil, flooding gradient, soil microbial communities, microbial guilds

Posted Date: June 25th, 2021

DOl: https://doi.org/10.21203/rs.3.rs-650987/v1

License: (c) (1) This work is licensed under a Creative Commons Attribution 4.0 International License.

Read Full License 


\section{Abstract}

Soil physico-chemical characteristics of floodplains, particularly hydrology, influence microbiological activity. As such, each river floodplain system has a unique physico-chemical dynamic that in turn supports the microbial community. The Mapire River floodplain is a complex system in which seasonal flood pulses cause changes in the soil physico-chemical variables. We examined how these temporal and spatial differences are associated with the microbiological activity along a seasonally flooded gradient at the mouth of the Mapire River (Lower Orinoco, Venezuela). Soil samples were collected during three different seasons by a systematic sampling at 4 points of the gradient, defined by the intensity of flooding. The physico-chemical parameters of the soil were determined and related by the density and physiological profile of the microbial community through multivariate permutation analysis and gradient analysis. The results indicate that there is a spatial gradient determined by soil clay content and a temporal gradient influenced by moisture and total organic carbon. Significant differences were found among soil zones and seasons, with the interaction of both factors also significant. It was observed that microbial activity is decisive in phosphorus dynamics, even during flooding. It is concluded that amid the complex interactions between biotic and abiotic factors, microbial communities are able to respond to changes in the physico-chemical soil environment and maintain their activity throughout the hydroperiod.

\section{Introduction}

Floodplain soils are semi-terrestrial comprised of periodic deposition of suspended river sediments during flood events (Rinklebe et al. 2007; Luster et al. 2014) and with fluctuating soil moisture conditions depending on water table (Gutknecht et al., 2006; Shaheen et al. 2014). Floodplain hydrology is therefore a major factor impacting the soil microbial community (Bossio and Scow 1995; Rinklebe and Langer 2010). Soil physico-chemical characteristics such as $\mathrm{pH}$, humidity, and nutrients act as control agents for microbial activity, promoting changes in biogeochemical cycles however, hydrology is considered as the most important driver (Gutknecht et al. 2006; Ou et al. 2019). Several studies indicate that microbial activity depends on soil aeration, which is affected by flooding (Gutknecht et al. 2006). Moreover, under soil saturation conditions nutrient loss occurs due to volatilization or runoff, immobilization of reduced substances such as ammonium, nitrite and sulfide, and mobilization of phosphate due to iron reduction (Ou et al. 2019). These processes of nutrient transformation and mobilization cannot be generalized and are the result of the unique dynamic interaction of floodplain and hydrology (Noe and Hupp et al. 2007).

Little is known about the biogeochemical cycles of the Mapire River, a tributary of the Orinoco River, Venezuela. The Mapire River is classified as "blackwater" due to its dark brown color and its oligotrophic character (Vegas-Vilarrúbia and Herrera 1993). When these waters flow into the Orinoco River a natural damming phenomenon occurs due to the water density differences. Consequently, the mouth of the Mapire River transforms into a complex floodplain system by damming produced by Orinoco River during the rainy season. Such flooding processes occur widely in the lower Orinoco. 
The longitudinal gradient of flooding that determines water depth and flood duration is dependent on local topography, and this variable flood intensity produces differences in the floristic composition and structure of the forest along the topographic gradient (Rosales 1989). These topographic and floristic variations likely promote changes in the physico-chemical conditions of the floodplain soil and therefore the dynamics of soil microbial communities (Zamora and Malaver 2019). Here, we assess seasonal changes in physico-chemical parameters of soil and their effect on microbial activity, particularly on the density of bacterial groups associated with biogeochemical processes and the functional structure of the soil microbial community for the Mapire River floodplain.

\section{Materials And Methods}

The study site was located in SE Venezuela $\left(N 7^{\circ} 44^{\prime}, \mathrm{W} 64^{\circ} 45^{\prime}\right)$ in the floodplain at the mouth of the Mapire River in the lower Orinoco basin (Fig. 1). The Mapire River is a northern tributary of the lower Orinoco River. The annual mean temperature is $27.4^{\circ} \mathrm{C}$ and the annual precipitation averages $1.333 \mathrm{~m}$. The dry season is between November and April and the rainy season from May to October (VegasVilarrúbia and Herrera 1993). This study was carried out in the igapó forest, characterized by Rosales (1989) according to the vegetation type and low soil fertility. No agricultural fields, that could affect the soil chemistry, were nearby.

The study was conducted throughout a complete natural hydroperiod: dry season (T1, March), onset of rains (T2, May) and flood season (T3, August). The topographic gradient was previously delimited and characterized by Rosales (1989) and Chacón et al. (2005): (i) zone of maximum flood depth (MAX) where floodwaters reach a maximum of up to $12 \mathrm{~m}$ for eight months a year (May to December); (ii) zone of intermedium flood depth (MED) where floodwaters reach a maximum of up to $5 \mathrm{~m}$ during five months a year (June to November); and (iii) zone of minimum flood depth (MIN) where floodwaters reach a maximum of $1 \mathrm{~m}$ depth only two months a year (July to September) and (iv) the highest elevation zone (NF) which never floods. Soil samples were collected in each of the three seasons from the four zones from the surface mineral horizon $(0-10 \mathrm{~cm})$ in twelve points arranged into three transects $(400 \mathrm{~m}) 1.5 \mathrm{~m}$ apart (Fig. 2), a sufficient distance for there to be heterogeneity in microbial composition (Vos et al. 2013). At each sampling point, three soil cores (8 $\mathrm{cm}$ inside diameter) were collected to form a composite sample for each point ( $n=3$ composite samples per zone and collection date, total $n=36$ ).

Soil samples were dried at ambient temperature (except those used to determine moisture content and for microbiological evaluation), sieved (mesh \#10), and homogenized prior to analysis. Soil texture was determined for each sample using the Bouyucos hydrometer method (Day 1965). Soil water content was determined according Richards (1941) and reported as percent humidity $(H \%)$. Soil pH was measured in a 1:2.5 ratio soil:water mixture (Jackson 1976) with a standard glass electrode (HORIBA). Total organic carbon (Ct) and soluble carbon (Cs) were measured by the complete oxidation method (Walkley and Black 1934). Total Kjeldahl nitrogen (Nt) followed Anderson and Ingram (1993). Total phosphorus $\left(P_{t}\right)$ was extracted by binary digestion with concentrated nitric and perchloric acids (Anderson and Ingram 1993) and determined using an autoanalyzer (Technicon AA). Available phosphorus $\left(P_{d}\right)$, or labile soil 
phosphorus, was extracted using an anion exchange resin (Tiessen and Moir 1993). The phosphate in the resin was desorbed with $0.1 \mathrm{M} \mathrm{H}_{2} \mathrm{SO}_{4}$ and determined colorimetrically by the molybdate-ascorbic acid method (Murphy and Riley 1962). Exchangeable calcium $\left(\mathrm{Ca}^{+2}\right)$, magnesium $\left(\mathrm{Mg}^{+2}\right)$, potassium $\left(\mathrm{K}^{+}\right)$and sodium $\left(\mathrm{Na}^{+}\right)$cations were determined by atomic absorption spectrophotometry (Thomas 1982).

Exchangeable acidity $\left(\mathrm{H}^{+}\right)$and aluminum $\left(\mathrm{Al}^{+3}\right)$ were extracted with $1 \mathrm{M} \mathrm{KCl}$ and titrated with $0.1 \mathrm{M} \mathrm{NaOH}$ and $0.1 \mathrm{M} \mathrm{HCl}$, respectively to determine their concentrations (McLean 1965). Fe (II) ions were extracted with $0.5 \mathrm{~N} \mathrm{HCl}$ (Chao and Zhou 1983) and quantified using the ferrozine colorimetric method (Stookey 1970). Ammonium $\left(\mathrm{NH}^{+}\right)$was extracted with $0.01 \mathrm{M} \mathrm{CaCl}_{2}$ (Anderson and Ingram 1993) and quantified by colorimetry at $690 \mathrm{~nm}$. Nitrate ions $\left(\mathrm{NO}_{3}\right)$ were extracted with $0.01 \mathrm{M} \mathrm{CaCl}_{2}$ (Anderson and Ingram 1993) and quantified by colorimetry using the nitration technique (Keeney and Nelson 1982). The data matrix of physico-chemical variables is shown in Supplementary Table S1.

The total number of culturable bacteria and fungi were counted as colony forming units (CFUs) on agar plates using the dilution plate method. Suspensions were serially diluted and plated on trypticase soy agar for aerobic bacteria, thioglycolate agar for anaerobic bacteria and malta agar for fungi. Plates were incubated at $26^{\circ} \mathrm{C}$ for $24 \mathrm{~h}$ for bacteria and $72 \mathrm{~h}$ for fungi. A GasPack System was used for anaerobic bacteria incubation. A total of 30 strains of aerobic bacteria and 30 strains of anaerobic bacteria for each gradient zone (10 strains per season and site) and all morphologically distinct fungal strains (filamentous and yeast) were randomly isolated from each replicate.

Density of sulfate and iron reducing, methanogenic and nitrifying bacteria was estimated by most probable number (MPN) in 5 test tube series. Methanogenic bacteria were cultured in $9 \mathrm{ml}$ of a basic anaerobe culture medium (Ravott et al. 1995) supplemented with $15 \%$ sodium acetate and with inverted Durham tubes. Test tubes were incubated at ambient temperature for $60 \mathrm{~d}$ under anaerobic conditions. Gas formation in Durham tubes indicated formation of methane from acetate (Fernández et al. 2006). Ferrous bacteria were cultured similar to methanogenic bacteria but with the addition $10 \%$ iron citrate. Tubes were incubated for $30 \mathrm{~d}$ at ambient temperature under anaerobic conditions. Reduction of $\mathrm{Fe}$ (III) to $\mathrm{Fe}$ (II) in the medium was evident by a change in color from yellow to transparent (Fernández et al. 2006). Sulfate reducing bacteria (SRB) were cultured using a modification of the Baars method (Zamora and Malaver 2012). The tubes were incubated in the dark and at ambient temperature for $14 \mathrm{~d}$ under anaerobic conditions. The presence of SRB was identified by precipitation of ferrous sulfide (FeS; black color). Nitrifying bacteria were cultured following Garassini (1962). Test tubes were incubated for $21 \mathrm{~d}$ at ambient temperature. The presence of nitrates in the medium was identified by adding sulfuric diphenylamine (blue color).

The functionality of each isolated bacterial and fungal strain was characterized using 14 biochemical tests related to mineralization of soil organic matter including: glucose, lactose, peptones (with Kliger agar), starch, production of urease (with urea medium), proteases (with gelatin nutritive medium), and nitrate reductases (with nitrate agar) (MacFaddin 2004). Hydrolysis of cellulose, lignin, chitin, pectin and inositol hexaphosphate was determined according to Parkinson et al. (1971). Lipase production was 
determined using Tween 80 as substrate in the Tween Opacity Test (Slifkin 2000) and solubilization of phosphates using Pikovskaya's agar. Results were expressed as frequencies of use of each substrate (number of positive responses) with respect to the total number of strains (Supplementary Table S2).

Granulometric difference in soils among gradient zones was tested with one-way analysis of variance (ANOVA). A two-way multivariate ANOVA based on permutations (PERMANOVA) was used to test the null hypothesis of no differences in physico-chemical and microbiological condition among gradient zones and seasons. The PERMANOVA was performed using a Euclidean distance matrix for physico-chemical data to avoid the effect of units and Bray-Curtis distance matrix for microbiological data to determine the similarity in the responses of the different substrates. The data were previously transformed with square roots and normalized. The statistical significance of the PERMANOVA was tested with 9999 Type III sum of squares (SS) permutations and a reduced model to generate a permuted F-statistic and a $p$-value. When significant differences were found, the variables that contributed the most to the differences were identified through a SIMPER analysis (Anderson et al. 2006). A Canonic Redundancy Analysis (RDA) was used to determine the influence of the environmental variables on the microbiological variables. All statistical analyses were performed with PRIMER 6 \& PERMANOVA+V6.1.16 and CANOCO 4.5 software (Braak and Smilauer 1997).

\section{Results}

A texture gradient was observed from the MAX area to the NF area, defined by sand and clay content (Table 1). The MED area presented a greater percent of clay with respect to other areas and the MIN and $\mathrm{NF}$ areas had greater sand content than lower areas of the gradient. The texture gradient from the MAX to the NF zone is determined by an increase in sand content thus, NF and MIN areas are better drained than MAX and MED areas.

Table 1

Soil texture of the different areas of the flooding gradient

\begin{tabular}{|c|c|c|c|c|}
\hline \multirow[t]{2}{*}{ Zone } & \multicolumn{4}{|l|}{ Texture } \\
\hline & \%Clay & \%Silt & \%Sand & Textural Class \\
\hline MAX & $54,17 \mathrm{~b}$ & 23,33 a & $22,5 b$ & Clayey \\
\hline MED & $65 a$ & 20,83 a & $14,17 \mathrm{c}$ & Clayey \\
\hline MIN & $21,67 c$ & 20,83 a & 57,5 a & Sandy Clayey Loam \\
\hline NF & $18,33 \mathrm{c}$ & $20 \mathrm{a}$ & $61,67 a$ & Sandy Loam \\
\hline \multicolumn{5}{|c|}{$\begin{array}{l}\text { Mean followed by different letters in the same column indicate statistically significant differences } \\
\text { (ANOVA, } p \leq 0.05, n=3 \text { ). MAX, maximum flood zone. MED, medium flood zone. MIN, minimum flood } \\
\text { zone. NF, not flooded area. }\end{array}$} \\
\hline
\end{tabular}


The PERMANOVA analysis indicated significant differences $(p<0.05)$ among the different zones of the gradient and across the different periods for both physico-chemical and microbiological variables (Tables 2 and 3 ). The interaction between the seasons and zones was also significant $(p<0.05)$ for both physicochemical and microbiological variables. PERMANOVA analysis of the physico-chemical variables (Table 2) indicated that the spatial factor had greater relevance than the temporal factor. Season explained $15.53 \%$ of the variance of soil physico-chemical conditions and zone explained $34.86 \%$ of the variance and $27.74 \%$ of the variance was explained by the interaction of both factors (Table 2). The physico-chemical variable that contributed most to the spatial differences among zones is $\mathrm{NO}_{3}$ while temporal differences among the seasons were mainly due to $C_{t}$ (SIMPER, Supplementary Table S3).

Table 2

PERMANOVA analysis of physicochemical properties of the soil along the flooding gradient.

\begin{tabular}{|llllll|}
\hline Variable & d.f. & SS & PseudoF & $\mathbf{P}_{\text {perm }}$ & $\%$ CV \\
\hline Season & 2 & 90.432 & 9.52 & 0.001 & $15.53 \%$ \\
\hline Zone & 3 & 218.68 & 15.35 & 0.001 & $34.86 \%$ \\
\hline Season x Zone & 6 & 136.94 & 4.80 & 0.001 & $27.74 \%$ \\
\hline Residual & 24 & 113.95 & & & $21.86 \%$ \\
\hline Total & 35 & 560.00 & & & \\
\hline $\begin{array}{l}\text { d.f. degrees of freedom. SS sum of squares. PseudoF permutated F-statistic. Pperm permutated P- } \\
\text { value. \% CV percent coefficient of variation. }\end{array}$
\end{tabular}

Table 3

PERMANOVA analysis of microbiological variables of the soil along the flooding gradient.

\begin{tabular}{|lccccc|}
\hline Variation source & d.f. & SS & PseudoF & P $_{\text {perm }}$ & $\%$ CV \\
\hline Season & 2 & 12566 & 939,63 & 0.001 & $34.07 \%$ \\
\hline Zone & 3 & 5675,2 & 282,91 & 0.001 & $13.64 \%$ \\
\hline Season x Zone & 6 & 14370 & 358,19 & 0.001 & $51.86 \%$ \\
\hline Residual & 24 & 160,48 & & & $0.44 \%$ \\
\hline Total & 35 & 32772 & & \\
\hline $\begin{array}{l}\text { d.f. degrees of freedom. SS sum of squares. PseudoF permutated F-statistic. Pperm permutated P- } \\
\text { value. \%CV percent coefficient of variation. }\end{array}$ \\
\hline
\end{tabular}

PERMANOVA analysis of the microbiological variables showed that season explained the $34.07 \%$ of the variance while zone explained $13.64 \%$ of the variance and $51.86 \%$ the variability was explained by the interaction of season and zone (Table 3 ). The microbial characteristics that predominantly described 
spatial and temporal differences in the flood gradient were the density of ferrous, methanogenic, nitrifying and sulfate-reducing bacteria (SIMPER, Supplementary Table S4).

Redundancy analysis indicated that the change in the functional structure of the microbial community was associated with temporary variations in the physico-chemical parameters of the soil, mainly $\mathrm{N}_{\mathrm{t}}, \mathrm{Fe}(\mathrm{II})$, $\% \mathrm{H}, \mathrm{C}_{\mathrm{s}}$ and $\mathrm{P}_{\mathrm{d}}$ (Fig. 3) and spatial variations determined by sand and clays content. At $\mathrm{T} 1$, the clay soils of the MAX and MED zones were related to greater concentrations of Fe (II), Al ions, $N_{t}$ and $P_{t}$. The sandiest zones, MIN and NF, presented higher $\mathrm{C}_{t}, \mathrm{C}_{\mathrm{s}}$ and $\mathrm{NH}_{4}$. The physiological profile of the microbial community during this period was characterized by denitrification, the degradation of structural compounds such as cellulose, lignin, pectin and chitin, as well as enzymatic activity of ureases, lipases, and ta high density of ferrous bacteria. During T2, there was an increase in the density of anaerobic and nitrifying bacteria. The substrate use profile was characterized by consumption of labile carbohydrates, such as glucose and starch (activity of amylases), as well as a higher frequency of microorganisms with nitrate-reductase activity. The substrate use profile was mainly associated with variables such as $C_{t}, P_{d}$ and increased $\mathrm{pH}$ (Fig. 3). In T3, when moisture content reached maximum values ( $100 \%$ of the field capacity in the MAX and MED zones), $\mathrm{pH}, \mathrm{NO}_{3}$ and $\mathrm{P}_{\mathrm{d}}$ content also increased. The physiological profile of the microbial community was characterized by greater activity of proteinases and increases in the density of bacteria with anaerobic catabolism, such as anaerobic heterotrophic bacteria, and methanogenic and sulfate-reducing bacteria. In particular, a positive relationship was observed between the concentration of available phosphorus and the mineralization and solubilization of this element by the microorganisms. A positive relationship was also observed between available phosphorus and the density of ferrous and sulfate-reducing bacteria (Fig. 3).

\section{Discussion}

The vegetation in the floodplain of the Mapire River shows a differential zonation that responds to the flood gradient and the texture and chemical characteristics of the soil (Rosales 1989, Herrera 2013). Psidium ovalifolium (Myrtaceae) dominates the MAX zone, Pouteria orinocensis (Sapotaceae) and Eschweilera tenifolia (Lecithydaceae) the MED zone, and Ascomiun nitens (Papilionaceae) and Capsiandra laurifolia (Mimosaceae) dominate the MIN zone. Non-flooded area (NF) is an ecotone that is represented by species from the MIN zone and the adjacent Trachypogon spicatus (Poaceae) savanna.

Multivariate analyzes indicated a heterogeneous gradient of soil physico-chemical conditions, differentiated by soil textures between the zones, that in turn influences the temporal dynamics of nutrients (Table 2, Fig. 3), mainly nitrate and total carbon (Supplementary S3).

The soil texture gradient (Table 1) results from the sequence of sediment deposition according to the floodplain topography. Heavier sediments are washed away by floodwaters and deposited in areas farthest from the riverbed, whereas fine sediments are deposited by suspension in lower areas adjacent to the channel (Miller et al. 2001). The floodplain soils of Mapire River are very acidic $(\mathrm{pH}<5)$, attributable to exchangeable $\mathrm{Al}^{+3}$ and $\mathrm{H}^{+}$, the primary source of soil acidity (Chacón et al. 2005). However, during 
flooding there is a slight increase in soil pH (Supplementary S1), attributable to changes in redox potential and the reduction of Fe(III) to Fe(II) (Lin et al. 2018).

Thus, the structure of the soil microbial community in the Mapire River floodplain shows a complex spatio-temporal pattern (Table 3 ) in which the density of functional groups depends on the availability of resources (Fig. 3; Supplementary S4). The distribution of samples along the canonical axes (Fig. 3) reflects this seasonal pattern of the microbial community in response to physico-chemical soil conditions. In this work, the diversity of microbial species was not determined, but the functional structure (physiological profile) was used as an estimator of the structure of the microbial communities. The evaluation of the use of different carbon sources (physiological profile) by a microorganism or a consortium of them is a methodology that allows establishing the physiological profile of heterotrophic microbial assemblages capable of being metabolically active and culturable (Zamora et al. 2012). As an advantage, some research shows that these conventional microbiology methods, combined with a community ecology approach, can detect structural or functional changes in the soil microbial community (Xue et al. 2008; Huang et al. 2017).

During $\mathrm{T} 1, \mathrm{P}_{\mathrm{t}}$ was related to total nitrogen and clay content, consistent with Fassbender and Bonermisza (1987) who established that in the tropics the highest concentrations of $P_{t}$ are related to elevated clay and organic matter content. Total phosphorus in our study was also strongly correlated with Fe (II) ions similar to Chacón et al. (2008) who showed that the $\mathrm{P}_{\mathrm{t}}$ in these floodplain soils is adsorbed on iron and aluminum oxides. Total nitrogen was more elevated in the dry season associated with the ammonium (Fig. 3), possibly indicating a greater availability of organic substances (Yao et al. 1999). Correlated with the physico-chemical variables was the presence of microorganisms that degrade structural compounds. Cellullolytic, pectinolytic and lignolytic guilds were found in the MIN and NF zones, and chitinolytic and lipolytic guilds with urease activity and a high density of ferrous bacteria in the MAX and MED zones. One explanation for this pattern is that under dry conditions, vegetation loses its leaves and the accumulated leaf litter limits the type of microbial activity (Bastianoni et al. 2015). Litter contains a high content of structural compounds used by specific microbial groups (bacteria and fungi) (Smart and Jackson 2009) and consequently those guilds predominate.

Spatial variations in the distribution of guilds could be a consequence of differences in soil texture. The MIN and NF zones have a higher sand content and the porosity allows for greater oxygen diffusion. In contrast, the MAX and MED zones have more clay, less oxygen and therefore lower activity of the concomitant exoenzymes (Paul and Clark 1996; Balasooriya et al. 2008). In addition, the use of nitrogen compounds is related to the availability of $\mathrm{N}$ and therefore urease activity, indicating organic nitrogen mineralization is closely linked to the concentration of ammonium. Similarly, it was observed that the use of peptones as an energy source (carbohydrates generated during peptide hydrolysis) is closely related to nitrogen content, while protein hydrolysis is negatively correlated with $\mathrm{N}_{\mathrm{t}}$.

During the onset of the rainy season (T2), organic matter increased which allowed for greater expression of microbial guilds that metabolize simple carbohydrates such as glucose, lactose and starch. The 
increase in available organic carbon is attributed to an increased microbial biomass and activity because of the changes in soil moisture, the washing of nutrients from leaf litter, as well as lysis of microbial cells by osmotic shock caused by soil rewetting (Ou et al. 2019). Forest vegetation also increases microbial activity (Herrera 2013) providing radical exudates and leaf litter that function as substrate for microorganisms (Stoeckel and Miller-Goodman 2001). Interestingly, available phosphorus was correlated with total carbon (Fig. 3) suggesting that phosphorus balance in the soil is associated with mineralization of organic matter. Similar to T1, in T2 it was observed that the MIN and NF zones, with their predominance of sand, were characterized by a higher density of nitrifying bacteria whereas, the MAX and MED zones presented a higher density of methanogenic bacteria. This result is expected since heterotrophic nitrification is more relevant in acid soils (Myrold, 2005) and the initial wetting of soils at the start of the rainy season releases nitrogen from organic matter that becomes available for nitrification by aerobic acid-tolerant nitrifying bacteria (Randle-Boggis et al. 2018). This explains the observed correlation between the density of nitrating bacteria with the proteolytic activity of heterotrophic bacteria, since proteins are the main source of organic nitrogen in the soil and during their degradation mainly ammonium is released which serves as a substrate for the nitrating bacteria (Li et al. 2018).

Methanogenic bacteria were present in all zones of the gradient, although a higher density of methanogenic bacteria was quantified at the onset of the rainy season (T2) (Fig. 3). This is not unexpected since it has been previously reported that a low density of cultivable methanogenic bacteria can be found in well-drained soils (Hernández et al. 2019). Fermentative methanogenic bacteria maintain syntrophic relationships with other microorganisms such as facultative heterotrophic bacteria that, during incomplete oxidation of organic compounds, release intermediate metabolites such as pyruvate, formate, and alcohols, among others, as well as $\mathrm{H}_{2}$ and $\mathrm{CO}_{2}$ (Hornibrook et al. 1997). Additionally, acetogenic bacteria use $\mathrm{CO} 2$ and $\mathrm{H} 2$ to degrade these metabolites and produce acetate used as substrate by chemoorganotrophic methanogens (Hernández et al. 2019). In the present study, the methanogenic density was positively associated with the highest accumulation of available soil carbon consistent with Hornibrook et al. (1997) and Hernández et al. (2019), who established that the spatial distribution of fermentative methanogenic bacteria is determined by the availability of labile carbon.

At the end of the hydroperiod (T3), the soil microbial community remained active with a high density of fungi, also aerobic, anaerobic, and sulfate-reducing bacteria. Proteolytic guild was associated with an increase in $\mathrm{pH}$, nitrate, and available phosphorus (Fig. 3). Similar results were reported by Moche et al. (2015) who indicated that it is not the flood pulse that defines microbial activity, but rather, the availability of substrates in the soil, because the heterogeneity of litter in the soil guarantees a variety of substrates for microbial activity. They propose that the flood pulse determines the availability of carbon sources and this in turn influences community structure. The fact that aerobic bacteria density was not affected by flooding is attributed to the plasticity of the bacteria to adapt to different conditions. Fungal density, in contrast, was influenced by moisture and organic carbon content in soil consistent with Morton (2005). Fungi are heterotrophic microorganisms and their abundance and diversity is determined by the availability of oxidizable carbon substrates to obtain nutrients and energy. If there is no water available in 
the soil, fungi are unable to catalyze biochemical reactions (Paul and Clark 1996; Morton 2005). Nevertheless, although soil moisture favors the establishment and development of these microorganisms, the presence on the ground during the flood season indicates that fungi could be adapted to flood pulses.

Soil moisture also favors the activity of microorganisms that mineralize phosphorus and nitrogen, thus, the observed low or negative correlation with the degradation of structural polymers such as cellulose, lignin and chitin in this study. Although water is an essential factor for microbial activity, in soils with high clay content, moisture generates anoxic microzones where hydrolysis of complex organic compounds becomes inefficient (Wagner and Wolf 2005). The highest total nitrogen values were found in the MAX and MED zones because in these areas, the organic matter is greatest. In addition, inorganic nitrogen, in this type of soil, is less susceptible to runoff losses because of its adsorption on clays (Paul and Clark 1996). Use of nitrogen compounds is related to $\mathrm{N}$ availability, thus urease activity indicating nitrogen mineralization, is closely linked to the concentration of the $\mathrm{N}_{\mathrm{t}}$. Similarly, it was observed that the use of peptones as an energy source (carbohydrates generated during peptide hydrolysis) is closely related to nitrogen content, while protein hydrolysis is negatively correlated with $\mathrm{Nt}$ (Fig. 3). The nitrogen and phosphorus cycles are determined by the $\mathrm{C}: \mathrm{N}$ and $\mathrm{C}: \mathrm{P}$ ratios, since the extracellular enzymes responsible for the hydrolysis of organic compounds are inducible (Smart and Jackson 2009). Phosphatase enzymes carry out organic phosphorus mineralization and proteases are the analog for nitrogen (Wagner and Wolf 2005). These exoenzymes are sensitive to acidity and are mainly induced by a substrate deficiency in the soil solution (Nannipieri et al. 2012).

The fact that phosphorus mineralization by bacteria and fungi isolated from the floodplain was negatively associated with total phosphorus but positively correlated with available phosphorus (Fig. 3) indicates that microbial activity is a determinant in soil phosphorus dynamics even during flooding although other processes could also be involved. Chacón et al. $(2005,2008)$ suggest that during flooding, $P$ release from the geochemical pool can occur by microbial reduction of Fe (III) minerals. They argue that the bioavailability of phosphorus increases in the MAX and MED areas of the gradient as a result of the mineral dissolution process of iron and aluminum oxides. This suggestion may be supported by the present results that indicate a relationship between total phosphorus and the density of ferrous and sulfate-reducing bacteria, as well as the microbial solubilization of inorganic phosphorus in the MAX and MED zones (Fig. 3).

In summary, this study shows that the Mapire floodplain forest has very efficient mechanisms for capture and utilization of nutrients which agrees with previous studies carried out by Barrios and Herrera (1994). However, the results found in the present work only partially agree Balasooriya (2008), Mentzer (2006), Bossio and Scow (1995), among others, that soil moisture is the determining factor in the activity and composition of the soil microbial community. The present study determined that soil moisture and total organic carbon content are the main factors that determine microbial activity. However, these variables alone do not explain all the changes that occur along the flood gradient. The soil physico-chemical parameters affect microbial activity in a complex way and microbial communities respond to changes in 
the environment while maintaining their activity throughout the hydroperiod. The results of the present work are also consistent with Yu and Ehrenfeld (2010) who concluded that the depth of the water sheet, together with other soil factors, determines the differences in microbial communities in wetlands. Likewise, Lowell et al. (2009) reported that habitat heterogeneity, in the form of spatial differences in chemical properties and nutrient content of soils, determines the composition of the microbial community in floodplains.

\section{Conclusions}

The Mapire River flooplain presents a spatial gradient of physico-chemical conditions determined mainly by high clay content in the topographically lower zone (MAX and MED zones) and sand in the highest zone (MIN and NF zones). The physico-chemical characteristics generate a temporal gradient of conditions determined mainly by moisture and total organic carbon, and to a lesser extent by total phosphorus, total nitrogen and $\mathrm{pH}$. The relationships between the physico-chemical variables of the soil and the microbiological variables are not linear. The interaction between biotic and abiotic factors is complex and the microbial community maintains its activity despite the spatio-temporal heterogeneity of the soil. The biogeochemistry of the flooplain forest responds to changes in available nutrients, with mineralization of carbon compounds occurring mainly during the onset of rains whereas, different macronutrient release mechanisms, such as solubilization, are activated during the flood phase. Phosphorus solubilization, mineral hydrolysis and activation of enzymes (e.g., phosphatases, amylases, proteases) and use of electron acceptors are alternatives to oxygen to meet microbial nutrient and energy demands.

\section{Declarations}

\section{Acknowledges}

The authors thank Nelson Moncada and Jose Luis Vallés for their technical assistance during fieldwork. We thank PhD. Diana Papoulias for his helpful comments and improving the English language.

Funding: This research was funded by the National Fund for Science, Technology and Innovation (FONACIT) Project N²009000461.

Conflicts of interest/Competing interests: The authors declare no conflict of interest.

Ethics approval: Not applicable.

Consent to participate: Not applicable.

Consent for publication: Not applicable.

Availability of data and material: The authors agree to send all the data that is required. 
Code availability: Not applicable.

Authors' contributions: AZF and NM, conceptualization and methodology; AZF and IHV, data analysis and validation; AZF, IHV and NM, investigation; AZF and IHV, writing-original draft preparation; AZF and IHV, writing-review and editing; $A Z$ and NM, funding acquisition; NM, resources and project administration.

\section{References}

Anderson J, Ingram JS (1993) Tropical Soil Biology and Fertility: A Handbook of Methods. CAB International. Wallingford. UK.

Anderson MJ, Gorley RN, Clarke KR (2008). PRIMER+ for PERMANOVA: Guide to Software and Statistical Methods (Primer-E: Plymouth, UK).

Balasooriya WK, Denef K, Peters J, Verhoest NE, Boeckx P (2008). Vegetation composition and soil microbial community structural changes along a wetland hydrological gradient. Hydrology and Earth Systems Science Discussion 4: 3869 - 3907.

Barrios E, Herrera R (1994) Nitrogen cycling in a Venezuelan tropical seasonally flooded forest: Soil nitrogen mineralization and nitrification. Journal of Tropical Ecology 10(3): $399-416$.

Bastianoni A, Chacón N, Méndez CL, Flores S (2015) Decomposition dynamics of mixed litter in a seasonally flooded forest near the Orinoco river. Acta Oecologica 64: 21-28.

Bossio DA, Scow KM (1995) Impact of carbon and flooding on the metabolic diversity of microbial communities in soils. Applied Environmental Microbiology 61: 4043-4050.

Braak CJ, Smilauer P (1997) Canoco for Windows version 4.51. Biometris - Plant Research International. Wageningen, The Netherlands.

Chacón N, Dezzeo N, Muñoz B, Rodríguez JM (2005) Implications of soil organic carbon and the biogeochemistry of iron and aluminum on soil phosphorus distribution in flooded forest of the lower Orinoco River, Venezuela. Biogeochemistry 73: 555 - 566.

Chacón N, Dezzeo N, Rangel M, Flores S (2008) Seasonal changes in soil phosphorus dynamics and root mass along a flooded tropical forest gradient in the lower Orinoco River, Venezuela. Biogeochemistry 87:157-168.

Chao T.T, Zhou L (1983) Extraction techniques for selective dissolution of amorphous iron oxides from soils and sediments. Soil Science Society of America Journal 47: 225 - 232.

Day PR (1965) Particle fractionation and particle size analysis. In: Black CA (ed). Methods of soils analysis, Part 1. American Society of Agronomy, Madison, Wisconsin. pp 545 - 567. 
Fassbender H, Bornemisza W (1987) Química de Suelos, con énfasis en suelos de América Latina. Instituto interamericano de cooperación para la Agricultura. Editorial IICA. San José, Costa Rica.

Fernandez LC, Rojas NG, Roldán TG, Ramírez ME, Zegarra HG, Uribe R, Reyes RJ, Flores D, Arce JM (2006) Manual de técnicas de análisis de suelos aplicadas a la remediación de sitios contaminados. Instituto Mexicano del Petróleo. Secretaría del Medio Ambiente y Recursos Naturales. Instituto Nacional de Ecología. México DF.

Frohne T, Rinklebe J, Diaz-Bone RA (2014) Contamination of floodplain soils along the Wupper River, Germany, with $\mathrm{As}, \mathrm{Co}, \mathrm{Cu}, \mathrm{Ni}, \mathrm{Sb}$, and $\mathrm{Zn}$ and the impact of pre-definite redox variations on the mobility of these elements. Soil and Sediment Contamination: An International Journal 23(7): 779-799.

Garassini LA (1962) El suelo y su microflora. Revista de la Facultad de Agronomía UCV. Alcance $N^{\circ}$ 4. Caracas.

Gutknecht JL, Goodman RM, Balser TC (2006) Linking soil processes and microbial ecology in freshwater wetland ecosystems. Plant and Soil 289: 17-34.

Hernández M, Klose M, Claus P, Bastviken D, Marotta H, Figueiredo V, Enrich-Prast A, Corad R (2019) Structure, function and resilience to desiccation of methanogenic microbial communities in temporarily inundated soils of the Amazon rainforest (Cunia Reserve, Rondonia). Environmental Microbiology 21(5): $1702-1717$.

Herrera A (2013). Responses to flooding of plant water relations and leaf gas exchange in tropical tolerant trees of a black-water wetland. Frontiers in Plant Science 4: 106.

Hornibrook E, Longstaffe F, Fife W (1997) Spatial distribution of microbial methane production pathways in temperate zone wetland soils: Stable carbon and hydrogen isotope evidence. Geochimica et Cosmochimica Acta 61(4): 745 - 753.

Huang N, Wang W, Yao Y, Zhu F, Wang W, Chang X (2017) The influence of different concentrations of bioorganic fertilizer on cucumber Fusarium wilt and soil microflora alterations. PLoS One 12 (2):e0171490.

Jackson M (1976) Análisis químico del suelo. $3^{\text {ra }}$ ed. Omega, Barcelona.

Keeney DR, Nelson DW (1982) Nitrogen-inorganic forms. In: Page AL, Miller RH, Keeney DR (eds). Methods of soil analysis, Part 2. Madison Wisconsin. Agronomy 9: $643-698$.

Li Y, Chapman SJ, Nicol GW, Yao H (2018) Nitrification and nitrifiers in acidic soils. Soil Biology and Biochemistry 116: 290-301.

Lin Y, Bhattacharyya A, Campbell AN, Nico PS, Pett-Ridge J, Silver WL (2018) Phosphorus fractionation responds to dynamic redox conditions in a humid tropical forest soil. Journal of Geophysical Research: Biogeosciences 123(9): 3016 - 3027. 
Lowell J, Gordon N, Engstrom D, Stanford J, Holben W, Gannon J (2009) Habitat Heterogeneity and Associated Microbial Community Structure in a Small-Scale Floodplain Hyporheic Flow Path. Microbial Ecology 58: $611-620$.

Luster J, Kalbitz K, Lennartz B, Rinklebe J (2014) Properties, processes and ecological functions of floodplain, peatland, and paddy soils. Geoderma 228:1-4.

McFaddin J (2004) Pruebas Bioquímicas Para La Identificación De Bacterias De Importancia Clínica. $3^{a}$ Edición. Ediciones Panamericana, Buenos Aires.

McLean EO (1965) Aluminum. In: Black CA (ed). Methods of soils analysis. Part 2. American Society of Agronomy, Madison, Wisconsin, pp 985 - 994.

Mentzer JL, Goodman RM, Balser TC (2006) Microbial seasonal response to hydrologic and fertilization treatments in a simulated wet prairie. Plant and Soil 284: 85-100.

Miller AJ, Shuur EA, Chadwick OA (2001) Redox control of phosphorus pools in Hawaiian montane forest. Geoderma 102: 219 - 237.

Moche M, Gutknecht J, Schulz E, Langer U, Rinklebe J (2015) Monthly dynamics of microbial community structure and their controlling factors in three floodplain soils. Soil Biology and Biochemistry 90: 169-178.

Morton JB (2005) Fungi. In: Sylvia DM, Fuhrmann JJ, Hartel PG, Zuberer DA (eds). Principles and Applications of Soil Microbiology. Prentice Hall. New Jersey, pp. 141-160.

Murphy J, Riley JP (1962) A modified single solution method for the determination of phosphate in natural waters. Analytica Chimica Acta 27: 31-36.

Myrold DD (2005) Transformations of nitrogen. In: Sylvia DM, Fuhrmann JJ, Hartel PG, Zuberer DA (eds). Principles and Applications of Soil Microbiology. Prentice Hall. New Jersey, pp. $333-367$.

Nannipieri P, Giagnoni L, Renella G, Puglisi E, Ceccanti B, Masciandaro G, Fornasier F, Moscatelli MC, Marinari S (2012) Soil enzymology: classical and molecular approaches. Biology and Fertility of Soils 48:743-762.

Noe G, Hupp C (2007) Seasonal variation in nutrient retention during inundation of a short-hydroperiod floodplain. River Research and Applications 23: 1088 - 1101.

Ou Y, Rousseau AN, Wang L, Yan B, Gumiere T, Zhu H (2019) Identification of the alteration of riparian wetland on soil properties, enzyme activities and microbial communities following extreme flooding. Geoderma 337: 825-833.

Parkinson D, Gray TRG, Williams ST (1971) Methods for Studying the Ecology of Soil Micro-organisms. IBP Handbook No 19. International Biological Programme. Blackwell Scientific Publications, Oxford. 
Paul EA, Clark FE (1996) Soil Microbiology and Biochemistry. Academic Press, San Diego, California.

Randle-Boggis RJ, Ashton PD, Helgason T (2018). Increasing flooding frequency alters soil microbial communities and functions under laboratory conditions. Microbiology Open 7:e548.

Ravot G, Ollivier B, Magot M, Patel C (1995) Thiosulfate reduction, an important physiological feature shared by members of the order Thermotogales. Applied Environmental Microbiology 61: $2053-2055$.

Richards L (1941) A pressure membrane extraction apparatus for soil solution. Soil Science 51: 377 386.

Rinklebe J, Franke C, Neue HU (2007) Aggregation of floodplain soils based on classification principles to predict concentrations of nutrients and pollutants. Geoderma 141: 210-223.

Rinklebe J, Langer U (2010) Relationship between soil microbial biomass determined by SIR and PLFA analysis in floodplain soils. Journal of Soils and Sediments 10(1): 4-8.

Rosales J (1989) Análisis florístico-estructural y algunas relaciones ecológicas en un bosque inundable en la boca del río Mapire (estado Anzoétgui). Msc Thesis, Instituto Venezolano de Investigaciones Científicas, Caracas, 233 p.

Shaheen SM, Rinklebe J, Rupp H, Meissner R (2014) Lysimeter trials to assess the impact of different flood-dry-cycles on the dynamics of pore water concentrations of As, Cr, Mo and V in a contaminated floodplain soil. Geoderma 228: 5-13.

Slifkin M (2000) Tween 80 Opacity Test Responses of Various Candida Species. Journal of Clinical Microbiology 38(12): 4626-4628.

Smart K, Jackson C (2009) Fine Scale Patterns in Microbial Extracellular Enzyme Activity during Leaf Litter Decomposition in a Stream and its Floodplain. Microbial Ecology 58: 591 - 598.

Stoeckel DM, Miller-Goodman MS (2001) Seasonal Nutrient Dynamics of Forested Floodplain Soil Influenced by Microtopography and Depth. Soil Science Society of America Journal 65: 922-931.

Stookey LL (1970) Ferrozine: a new Spectrophotometric reagent for iron. Analytical Chemistry 42(7): 779 $-781$.

Thomas GW (1982) Exchangeable cations. In: Page AL, Miller RH, Keeney DR (eds). Methods of soil analysis, Part 2. Madison Wisconsin. Agronomy 9: 159-165.

Tiessen H, Moir JO (1993) Characterization of available P by sequential extraction. In: Carter MR (ed) Soil sampling and methods of analysis. Special publication of the Canadian Society of Soil Science. Lewis, Boca Raton, pp. 75-86. 
Vegas-Vilarrúbia T, Herrera F (1993) Effects of periodic flooding on thewater chemistry and primary production of the Mapire systems (Venezuela). Hydrobiologia 262: 31-42.

Vos M,Wolf AB, Jennings SJ, Kowalchuk (2013) Micro-scale determinants of bacterial diversity in soil. FEMS Microbiology Reviews 37: 936-954.

Wagner GH, Wolf DC (2005) Carbon transformations and soil organic matter formation. In: Sylvia DM, Fuhrmann JJ, Hartel PG, Zuberer DA (eds). Principles and Applications of Soil Microbiology 2nd edition. Prentice Hall, Upper Saddle River, New Jersey, pp. 218-258.

Walkley A, Black A (1934) An examination of the Degtjareff method for determining soil organic matter and a proposed modification of the chromic acid titration method. Soil Science 37: 29-38.

Xue D, Yao HY, Ge DY, Huang CY (2008) Soil microbial community structure in diverse land use systems: a comparative study using Biolog, DGGE, and PLFA analyses. Pedosphere 18(5):653-663.

Yu S, Ehrenfeld J (2010) Relationships among plants, soils and microbial communities along a hydrological gradient in the New Jersey Pinelands, USA. Annals of Botany 105: 185-196.

Zamora AC, Malaver N (2012) Methodological aspects for the culture and quantification of heterotrophic sulfate-reducing bacteria. Revista de la Sociedad Venezolana de Microbiología 32:121-125.

Zamora AC, Malaver N (2019). Dinámica de comunidades microbianas heterotróficas en la planicie de inundación del Río Mapire, Venezuela. Acta Biologica Venezuelica 39(1):49-71.

\section{Figures}




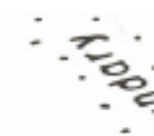

Savanna

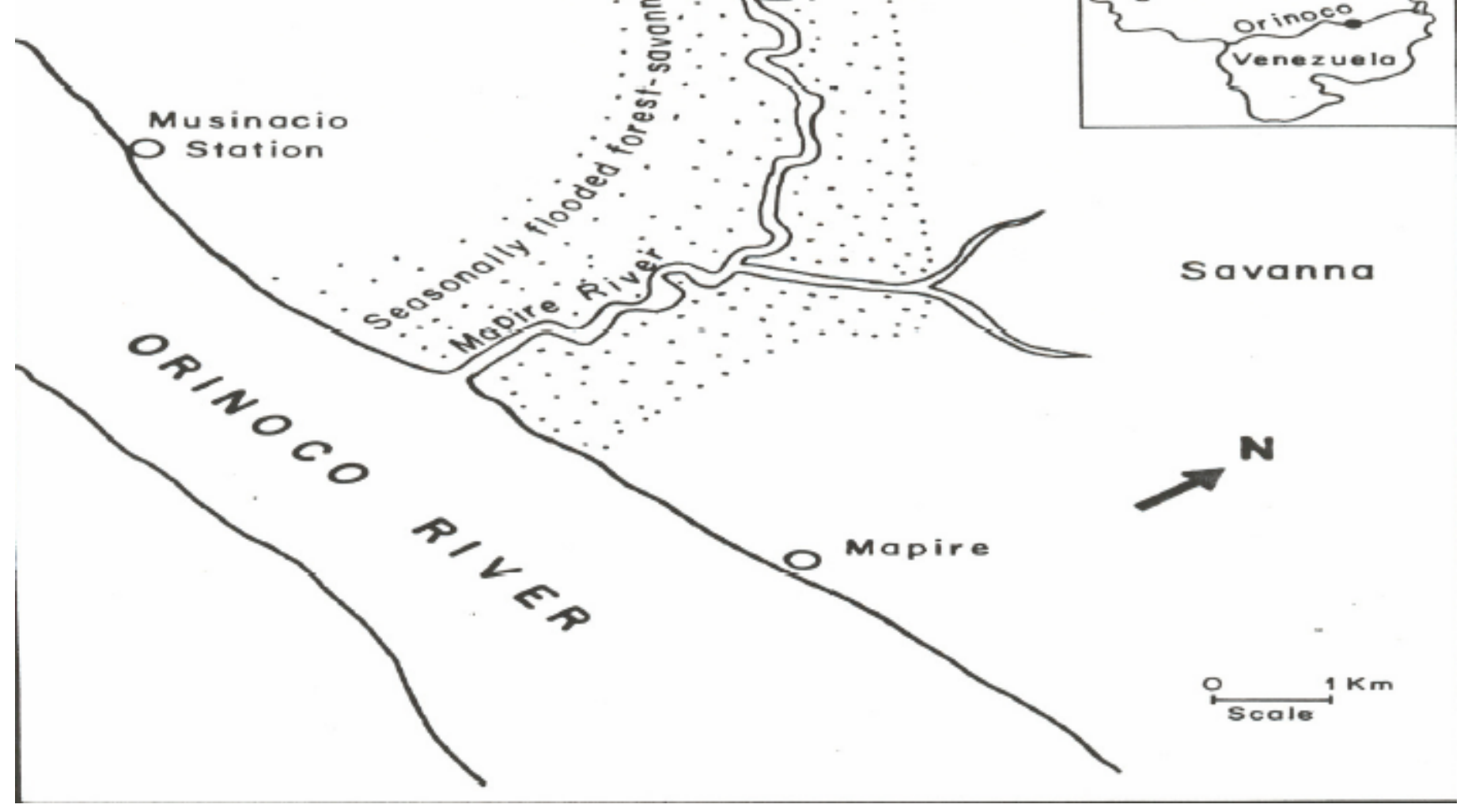

Figure 1

Geographical location of the floodplain of the Mapire River (taken from Barrios and Herrera 1994). 


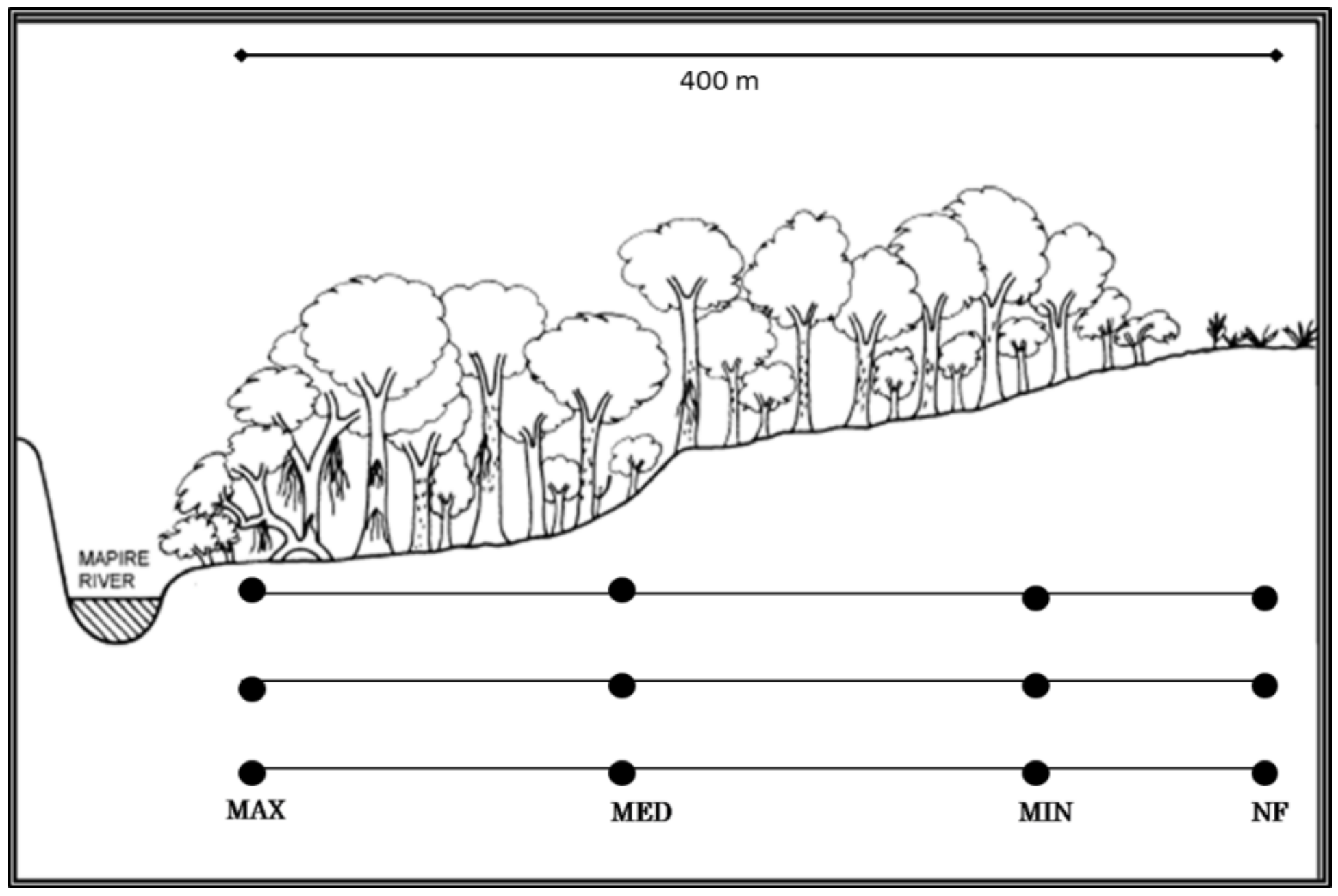

Figure 2

Soil sampling pattern in the different zones of the flooded forest gradient (adapted from Rosales, 1989). (•) sampling point. MAX, maximum flood zone. MED, medium flood zone. MIN, minimum flood zone. NF, not flooded area. 


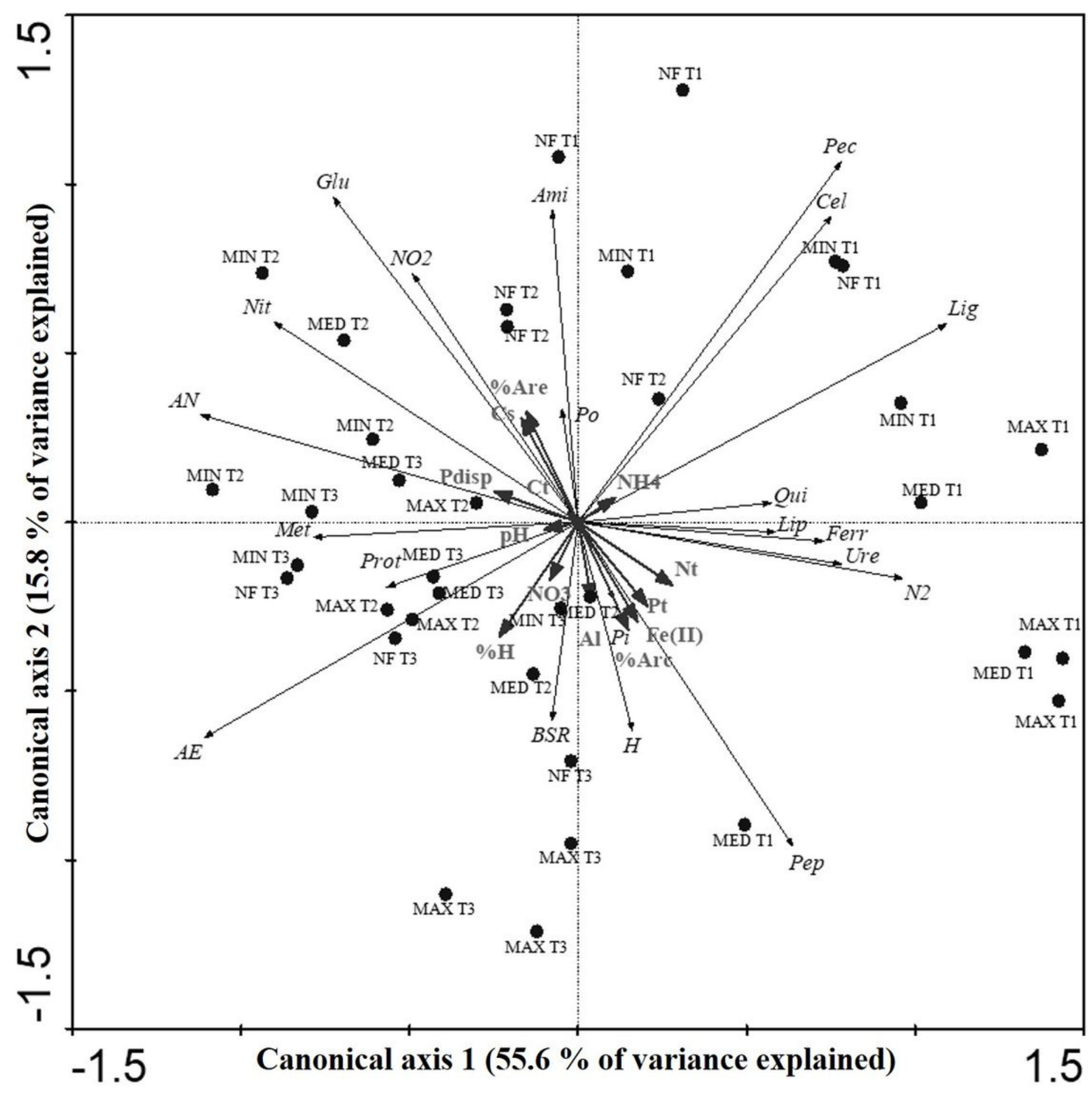

Figure 3

Canonical redundancy analysis triplot for descriptors of the microbial community according to the physicochemical variables along the flood gradient of the Mapire River across season studied. MAX, maximum flooded area. MED, intermediate flooded area. MIN, minimum flooded area. NF, no flooding area. T1, dry season. T2, beginning of rainy season. T3, flooding season. Dens AE, density of aerobic bacteria. Dens AN, density of anaerobic bacteria. Dens $\mathrm{H}$, density of fungi. DensFer, density of ferrous bacteria. DensBSR, density of sulfate reducing bacteria. DensNitra, density of nitrating bacteria. DensMet, 
density of methanogenic bacteria. Glu, glucose degradation. Pep, degradation of peptones. Ami, hydrolysis of starch. Pec, degradation of pectin. Cel, cellulose degradation. Lig, degradation of lignin. Qui, degradation of chitin. Prot, degradation of proteins (proteinases). Lip, lipid degradation (lipases). NO2, reduction of nitrates to nitrites (nitrate reductases). N2, denitrification (nitrate reductases). Ure, urea mineralization. $\mathrm{Pi}$, solubilization of phosphates. Po, phosphorus mineralization (phytinases). \% $\mathrm{H}$, humidity percentage. $\mathrm{Ct}$, total carbon. $\mathrm{Cs}$, soluble carbon. $\mathrm{Nt}$, total nitrogen. $\mathrm{NO}$, nitrate. $\mathrm{NH} 4$, ammonium. Pt, total phosphorus. Pd, available phosphorus. Al, exchangeable aluminium. Fe(II), cation ferrous. \%Arc, clay percentage. \%Are, sand percentage.

\section{Supplementary Files}

This is a list of supplementary files associated with this preprint. Click to download.

- ZamoraetalMapireSupplementary.docx 